\title{
Penanaman Nilai Karakter Melalui Permainan Outdoor Bagi Anak-Anak Usia Dini di Wilayah RW 01 Kelurahan Pekayon, Kecamatan Pasar Rebo, Jakarta Timur
}

\author{
Trie Utari Dewi ${ }^{1}$, Sri Lestari Handayani ${ }^{2}$ \\ ${ }^{1}$ Prodi Pendidikan Bahasa dan Sastra Indonesia FKIP UHAMKA \\ ${ }^{2}$ Prodi Pendidikan Guru Sekolah Dasar FKIP UHAMKA \\ ${ }^{1}$ trie.utari.dewi@uhamka.ac.id \\ 2yani26aryani@gmail.com
}

\begin{abstract}
ABSTRAK
Kegiatan pengabdian ini dilatarbelakangi permasalahan mitra yang diidentifikasi meliputi (1) Umumnya para guru di PAUD lebih banyak memberikan kegiatan di dalam ruangan, (2) Kurangnya inovasi para guru dalam memberikan metode pengajaran melalui permainan, (3) Pengajar di PAUD Rw 01 Kel. Pekayon Kec. Pasar Rebo adalah ibu-ibu PKK dan bukan lulusan dari perguruan tinggi pendidikan anak usia dini, (4) Anak-anak tidak dapat beraktivitas dengan bebas karena terbatas dengan ruang dan media permainan outdoor, (5) Anak-anak menjadi pasif dikarenakan bosan akan kegiatan di dalam ruangan terus menerus, dan (6) Karakter anak yang seharusnya tumbuh sejak dini menjadi terhambat. Adapun solusi yang ditawarkan ialah memberikan pelatihan dan pendampingan pelaksanaan permainan outdoor bagi guru dan siswa PAUD RW 01 Kelurahan Pekayon. Target luaran pengandian ini berupa jasa pelatihan dan pendampingan permainan outdoor bagi siswa dan guru PAUD RW 01 Kelurahan Pekayon yang dilaksanakan selama dua hari. Metode yang digunakan adalah metode ceramah, simulasi, dan diskusi. Hasil dari pelaksanaan kegiatan pengabdian masyarakat ini yaitu memberi gambaran dan arahan kepada guru bahwa melakukan penanaman karakter siswa dapat melalui permainan-permainan outdoor yang bersifat edukatif. Permainan-permainan outdoor yang bersifat edukatif memberi kesempatan kepada siswa belajar bekerjasama, kekompakan, toleransi, kejujuran, kedisiplinan, kerja keras, meningkatkan kreativitas, mandiri, demokratis, rasa ingin tahu, semangat kebangsaan, menghargai, kepemimpinan, kerjasama, peduli lingkungan, peduli sosial, tanggung jawab, religius, dan gemar membaca.
\end{abstract}

\section{Kata kunci: Nilai Karakter, Permainan Outdoor, Anak Usia Dini}

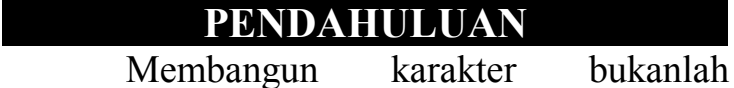

merupakan produk instant yang dapat langsung dirasakan sesaat setelah pendidikan tersebut diberikan. Pendidikan itu sendiri merupakan sikap sadar dan disengaja untuk mengembangkan potensi yang ada dalam diri anak, salah satunya adalah kekuatan karakter. Hal ini sebagaimana yang diungkapkan Khoiri (2018: 101) bahwa, Education is a conscious and deliberate effort to create an atmosphere of learning process for children to actively develop the potential for them to have the spiritual strength of religious, self-control, personality, intelligence, noble character, and the skills needed themselves and society. Selain itu, Marzuki dan Lysa Hapsari (2015) menyatakan bahwa pendidikan harus mampu mengemban misi pembentukan karakter atau akhlak mulia (character building) sehingga para siswa dan para lulusan lembaga pendidikan dapat berpartisipasi dalam mengisi pembangunan di masa-masa mendatang tanpa meninggalkan nilai-nilai moral atau akhlak mulia. Oleh karena itu, pendidikan membangun karakter merupakan proses panjang yang harus dimulai sejak dini pada anak-anak dan baru dirasakan setelah anakanak tersebut tumbuh menjadi dewasa. Salah satu metode yang dapat digunakan sebagai model pendidikan anak usia dini yaitu dengan bermain. Hal ini sejalan dengan pendapat Suyanto (2005 dalam Innayah) bahwa esensi pembelajaran pada PAUD adalah bermain. Pada umumnya anak belajar melalui bermain didalam lingkungan indoor, namun sebenarnya hal tersebut juga dapat dilakukan pada lingkungan outdoor. Lingkungan outdoor sendiri merupakan lingkungan yang berada di luar ruangan, di mana lingkungan ini merupakan bagian yang tak dapat dipisahkan dari keberhasilan belajar melalui bermain di lingkungan indoor, dan dapat mengembangkankan potensi yang dimiliki 
anak. Belajar dengan bermain di luar ruangan juga memiliki kelebihan tersendiri dibandingkan belajar di dalam ruangan saja. Hal ini sejalan dengan pendapat Amylia dan Sri Setyowati (2014) tentang kelebihan outdoor learning di antaranya dapat mendorong motivasi belajar pada anak dengan suasana belajar yang menyenangkan, menggunakan bahan alam yang sudah ada di sekitar dapat menumbuhkan kemampuan bereksplorasi serta bisa memberikan kesenangan pada anak ketika belajar tanpa ada rasa bosan dan jenuh. Dengan begitu, permainan outdoor juga dapat menghilangkan kejenuhan bagi anak-anak dari kegiatan belajar dan bermainan di dalam ruang kelas. Selain itu, permainan outdoor membuat anak-anak lebih bebas bergerak dengan leluasa, sehingga bakat-bakat yang ada dalam dirinyapun dapat dikeluarkan.

Adapun nilai karakter yang dapat ditanamkan melalui permainan outdoor adalah jujur, toleransi, disiplin, kerja keras, kreatif, mandiri, demokratis, rasa ingin tahu, semangat kebangsaan, kekompakan, cinta tanah air, menghargai, kepemimpinan, cinta damai, kerjasama, peduli lingkungan, peduli sosial, tanggung jawab, religius, dan gemar membaca. Permainan outdoor masih sangat minim baik dari segi pelaksanaan maupun fasilitas. Padahal permainan outdoor untuk anak usia dini bukan hanya permainan dengan media ayunan, perosotan, jungkat-jungkit, tangga panjat, atau yang lainnya. Permainan outdoor juga dapat dilakukan dengan media-media yang sederhana. Akan tetapi, permasalahannya adalah para pengajar yang belum tahu bagaimana cara memberikan permainan outdoor dengan media sederhana. Guru-guru lebih banyak menhabiskan waktu dengan kegiatan di dalam ruangan saja, sehingga terkadang membuat anak-anak menjadi bosan terhadap permainan di dalam ruangan. Padahal banyak cara untuk dapat menanamkan nilai karakter pada anak.

Berdasarkan hasil temuan penulis, anak-anak di PAUD Rw 01 Kel. Pekayon Kec. Pasar Rebo Jakarta Timur lebih banyak menghabiskan waktunya dengan kegiatankegiatan di dalam ruangan sehingga membuat mereka tidak leluasa bergerak atau mengekspresikan dirinya di dalam ruangan yang terbatas. Selain itu, kegiatan di dalam ruangan yang terlalu lama dan terus menerus juga menimbulkan kebosanan dan kejenuhan bagi anak. Padahal anak-anak di usia dini lebih senang jika beraktivitas di ruang terbuka dan alam bebas. Namun keterbatasan media permainan di luar ruangan atau outdoor membuat para guru tidak berdaya untuk memberikan kegiatan atau permainan di outdoor. Ditambah lagi dengan kapasitas pengajar di PAUD tersebut yang merupakan ibu-ibu PKK dan bukan lulusan dari perguruan tinggi pendidikan anak usia dini membuat para guru kurang inovatif dalam memberikan pengajaran dan permainan outdoor. Dampak dari semua permasalahan tersebut membuat sebagian besar siswa menjadi pasif dalam mengikuti kegiatan bermain dan belajar, sehingga berdampak pula pada perkembangan karakternya yang menjadi terhambat. Untuk itulah kegiatan PKM (Pengabdian Pada Masyarakat) berupa penanaman nilai karakter melalui permainan outdoor dirasa tepat untuk diberikan kepada anak-anak usia dini di PAUD wilayah RW 01 Kelurahan Pekayon dan dapat dijadikan contoh pengajaran melalui permainan outdoor untuk para pengajar di PAUD tersebut.

Dipilihnya workshop PKM Penanaman nilai karakter melalui permainan outdoor yaitu berdasarkan pertimbangan:

a) Permintaan khusus dari mitra.

b) Untuk menanamkan nilai karakter secara tidak langsung kepada anak melalui permainan outdoor.

c) Untuk memberikan contoh inovasi pembelajaran dan permainan di luar ruangan dengan media sederhana.

Pengusul dan mitra bersepakat memilih kegiatan PKM Penanaman nilai karakter melalui permainan outdoor agar anakanak tidak hanya melakukan aktivitas belajar dan bermainnya di dalam ruangan saja, tetapi juga di luar ruangan. Dengan begitu nilai karakter dapat tertanamkan dalam diri anak sejak dini secara tidak langsung. Selain itu, para guru juga dapat lebih kreatif dalam berinovasi menciptakan permainan outdoor sederhana yang dapat mengembangkan dan membangun karakter anak.

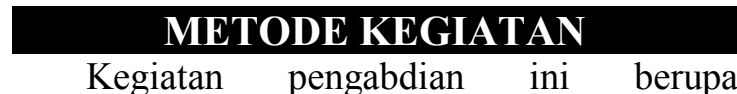
penanaman nilai karakter melalui permainan outdoor bagi anak usia dini di wilayah RW 01 kel. Pekayon, Kec. Pasar Rebo, Jakarta Timur. Kegiatan dilakukan selama 2 hari dengan jumlah peserta sebanyak 20 anak dan 6 orang guru. Setelah diberikan pengarahan tentang tata cara bermain, peserta diminta untuk mengikuti permainan yang telah diarahkan lalu didiskusikan dengan tanya jawab sehingga 
peserta paham akan nilai dan manfaat dari permainan yang dimainkan. Metode pelatihan kegiatan pengabdian yang digunakan yaitu: (1) Metode Ceramah, dipilih untuk memberikan pengarahan secara langsung permainan yang akan dimainkan, (2) Metode Simulasi, dipilih agar peserta dapat langsung mengikuti permainan sesuai dengan arahan yang telah diberikan, dan (3) Metode diskusi, dipilih agar peserta dapat mengetahui nilai dan manfaat yang dapat diperoleh dari permaina yang telah dimainkan.

Adapun langkah-langkah kegiatan yang dilakukan adalah sebagai berikut:

a) Tahap Persiapan

Tahap persiapan yang dilakukan meliputi survey, pemantapan dan penentuan lokasi sasaran, serta komunikasi dengan mitra melalui pengurus PAUD dan pengelola RPTRA serta mengurus surat kerjasama mitra.

b) Tahap Pelaksanaan

Tahap pelaksanaan di hari pertama dan kedua diberikan permainan outdoor yang berbeda-beda, di mana di dalamnya mengandung nilai karakter yang dapat diberikan kepada anak seperti kerjasama, toleransi, kekompakan, dan kejujuran.. Hari pertama diberikan tiga jenis permainan outdoor yaitu puzzle, bola emas, dan hujan salju. Hari kedua berisi tiga permainan outdour berupa estafet karet, all for one one for all, dan hydro tower.

c) Tahap Evaluasi

Tahap evaluasi yang dilakukan pada kegiatan pengabdian ini dengan melakukan diskusi dan wawancara tidak terstruktur kepada ketua RPTRA Kaca Piring dan guru PAUD di RW 01 Kelurahan Pekayon terkait kegiatan dua hari yang dilakukan tersebut.

\section{HASIL \& PEMBAHASAN}

Kegiatan pengabdian "PKM

Penanaman Nilai Karakter Melalui Permainan Outdoor Bagi Anak-anak Usia Dini di Wilayah RW 01 Kel. Pekayon Kec. Pasar Rebo Jakarta Timur" telah dilaksanakan pada tanggal 25-26 April 2018. Kegiatan ini dilaksanakan selama dua hari di mana masing-masing berlangsung selama 2 jam dari pukul 08.00 hingga 10.00 WIB bertempat di RPTRA Kaca Piring Jakarta Timur. Kegiatan pengabdian yang telah dilaksanakan menitikberatkan penanaman karakter siswa PAUD RW 01 Kelurahan Pekayon melalui berbagai jenis permainan outdoor yang menyenangkan dan edukatif.

Pada kegiatan hari pertama, tim pengabdian mendatangkan narasumber luar terkait permainan outdoor. Narasumber yang diundang merupakan narasumber yang sudah biasa melakukan kegiatan-kegiatan permainan outdoor dan merupakan trainer dari lembaga dan perusahaan motivasi. Pada hari pertama kegiatan pengabdian ini, narasumber tersebut memandu jalannya kegiatan permainan outdoor kepada anak-anak. Sebelum permainan dimulai, narasumber melakukan pendekatan kepada siswa-siswa PAUD RW 01 Kelurahan Pekayon melalui kegiatan icebreaking. Selanjutnya, narasumber memandu tiga jenis permainan yang telah disiapkan yaitu puzzle, bola emas, dan hujan salju. Permainan pertama adalah permainan puzzle. Siswa-siswa tersebut dikelompokkan menjadi empat kelompok. Permainan-permainan yang dilaksanakan mengharuskan siswa berkelompok dan saling bekerjasama antar siswa. Siswa yang bekerja dalam kelompok dapat saling membantu dan bekerjasama menyelesaikan permainan untuk mencapai kemenangan bersama.

Puzzle yang digunakan yaitu bergambar seorang siswa memakai baju koko dan peci, di sisi lain puzzle terdapat doa keluar wc. Puzzle ini dipilih agar siswa-siswa PAUD RW 01 Kelurahan Pekayon dapat mencontoh dan dapat menghafal kemudian menerapkan bacaan doa yang mereka satukan secara lengkap. Karakter religi dan senantiasa mengamalkan ajaran-ajaran Islam menjadi nafas kegiatan pengabdian ini.

Permainan kedua berupa permainan bola emas. Cara melaksanakan permainan bola emas ini adalah Anak-anak dibuat kelompok beregu yang terdiri dari 4-5 anak, Salah satu anggota tiap kelompok matanya ditutup dan ditugaskan mengambil bola yang berwarna emas atau kuning yang sudah dicampur dengan bola warna lainnya, sedangkan anggota kelompok lainnya mengarahkan temannya untuk memilih bola berwarna emas atau kuning. Yang paling banyak dan cepat mengumpulkan bola berwarna emas atau kuning, dialah pemenangnya. Karakterkarakter yang diharapkan dapat terbentuk pada diri siswa melalui permainan bola emas adalah melatih sportifitas anak agar tidak berbuat curang, rasa saling menghargai dengan mendengarkan kata-kata teman, kekompakan anak, dan meningkatkan tanggung jawab anak karena dipilih untuk mewakilkan temantemannya yang lain.

Permainan ketiga adalah permainan hujan salju. Siswa diminta untuk duduk berbaris sesuai kelompok. Siswa yang duduk paling depan diminta mengambil tepung 
dengan tangan dan mengopernya ke teman di belakangnya tanpa berbalik badan. Kelompok yang paling banyak mengumpulkan tepung merekalah yang menang. Manfaat permainan hujan salju untuk siswa di antaranya yaitu kekompakan anak, kerjasama, melatih kedisiplinan agar mengoper tepung sesuai dengan teman barisannya, dan melatih sportifitas anak agar tidak berbuat curang dengan tidak berbalik arah badan.

Hari kedua dilaksanakan permainan lanjutan bagi siswa. Hari kedua pengabdian ini lebih menekankan pada pendampingan permainan outdoor bagi guru-guru PAUD RW 01 Kelurahan Pekayon oleh tim pelaksana pengabdian. Tim pelaksana pengabdian tetap terlibat untuk memandu dan membimbing guru-guru PAUD RW 01 Kelurahan Pekayon mulai dari awal hingga akhir pembelajaran. Kegiatan yang dilakukan pada hari kedua berupa permainan estafet karet, one for all all for one atau estafet bola, dan hydro tower atau air tumpah. Hari kedua diawali dengan guru membuka pembelajaran, berdoa sebelum belajar, dan melakukan ice breaking. Melalui kegiatan ice-breaking guru dapat menjadikan siswa untuk meningkatkan suasana hati yang gembira sehingga proses pembelajaran dapat berjalan dengan kondusif. Setelah kegiatan icebreaking guru menyiapkan siswa untuk mengikuti permainan outdoor dan membentuk siswa ke dalam kelompok sama seperti hari pertama.

Permainan pertama pada hari kedua adalah esfatet karet. Alat yang digunakan pada permainan estafet karet ini hanya dua yaitu karet dan sedotan plastik. Cara bermainnya adalah Anak-anak dibuat kelompok beregu seperti hari sebelumnya, lalu berbaris ke belakang. Selanjutnya, masing-masing anak diberikan satu sedotan dan diletakkan di mulut. Anak yang paling depan diberikan karet gelang untuk dioper ke teman di belakangnya melalui sedotan yang diletakkan di mulutnya, begitu seterusnya hingga teman yang paling belakang mengumpulkan karet sebanyak-banyaknya. Kelompok yang paling banyak mengumpulkan karetlah yang menang.
Melalui permainan ini, terdapat beberapa manfaat penanaman karakter kepada siswa yaitu kekompakan anak, kerjasama, melatih kesabaran, melatih sportifitas anak agar tidak berbuat curang dengan menggunakan tangan dalam memindahkan karet, dan kehati-hatian.

Permainan kedua disebut one for all all for one atau estafet bola. Alat yang digunakan dalam permainan ini adalah bola warna dan paralon yang dibelah-belah. Cara memainkan permainan tersebut adalah siswa berbaris sesuai kelompoknya, lalu masingmasing anak diberikan satu potong paralon dan dipegang dengan kedua tangan. Anak yang paling depan diberikan bola yang diletakkan di paralon yang dipegangnya dan harus mengoper ke teman di belakangnya tanpa menyentuh bola, dan yang dapat mengoper bola sampai akhir dan terbanyak, merekalah yang menang. Penanaman karakter melalui kegiatan ini adalah melatih kesabaran, kekompakan anak, kerjasama, mendisiplinkan anak agar bersikap jujur, ketepatan dalam bertindak, selalu konsentrasi, dan kehati-hatian.

Permainan ketiga adalah hydro tower atau air tumpah. Permainan ini dilakukan secara berkelompok. Alat yang dibutuhkan pada permainan ini adalah pipa paralon panjang yang telah diberi lubang kecil-kecil pada dinding pipa, gayung, ember, bola, dan air.

Anak-anak dibuat kelompok beregu yang terdiri dari 4-5 anak. Tiap kelompok menunjuk satu orang anggota yang ditugaskan menuangkan air, dan yang lainnya ditugaskan untuk menutupi lubang yang terdapat pada pipa. Pipa harus diisi dengan air yang diambil dengan menggunakan gayung hingga bola yang terdapat di dalam pipa dapat keluar. Yang paling cepat mengeluarkan bola di dalam pipa yang menjadi pemenangnya. Penanaman karakter yang diharapkan melalui permainan ini adalah menjalin kekompakan, kerjasama, berani menyelesaikan tantangan, melatih kesabaran, belajar bertanggungjawab atas tugas masing-masing, dan rela berkorban demi mencapai tujuan bersama.
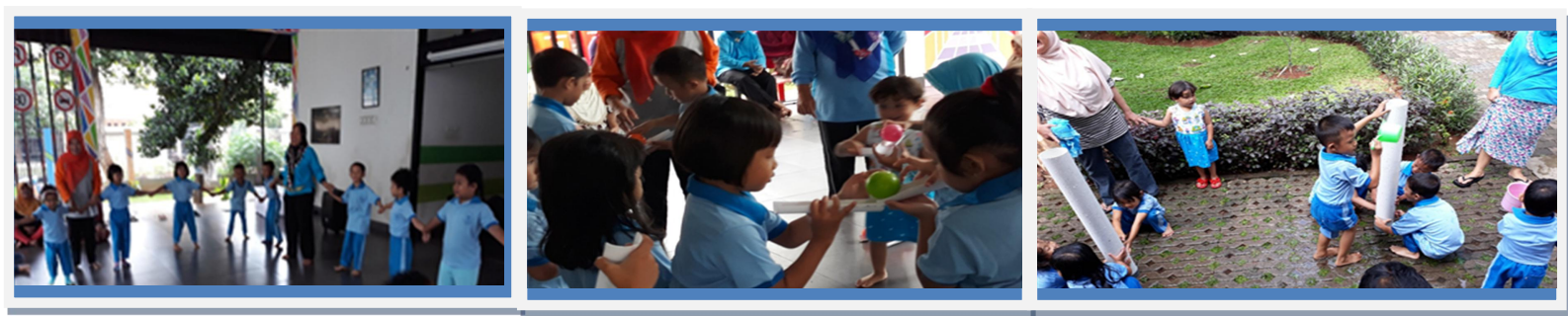

Gambar 1. Foto kegiatan Permainan Outdoor 
Kehidupan anak senantiasa tidak lepas dari kegiatan bermain. Kegiatan bermain menjadi salah satu kesempatan bagi guru-guru PAUD untuk melakukan pendidikan karakter. Pembelajaran di luar ruangan (outdoor) yang bersifat edukatif dapat menjadi cara efektif dalam penanaman karakter bagi siswa PAUD RW 01 Kelurahan Pekayon. Menurut (Abdullah, Hastuti, \& Karmila, 2015) metode permainan adalah metode yang tepat untuk mengeksplorasi dan mengembangkan bakat yang dimiliki siswa. (Susilowati, 2014) menyatakan bahawa untuk anak usia dini membutuhkan pembelajaran yang melalui aktivitas langsung karena anak usia dini berada pada tahap konkrit-operasional. Pada tahap perkembangan tersebut, pembelajaran yang dimunculkan berupa pembiasaan termasuk pembentukan karakter siswa.

Penanaman karakter siswa dapat melalui pembiasaan dengan metode permainan outdoor. Hal ini sejalan dengan (Fadlillah, 2016) yang menyimpulkan bahwa nilai-nilai karakter dapat dikenalkan dan ditanamkan kepada anak-anak sejak dini melalui permainan edukatif.

Penanaman karakter melalui permainan outdoor yang telah dilakukan dapat dilakukan tanpa kesulitan berarti. Hal ini tampak pada keaktifan peserta dalam mengikuti permainan puzzle, bola emas, hujan salju, estafet karet, all for one one for all, dan hydro tower.

Berdasarkan hasil evaluasi dengan mitra, diperoleh beberapa informasi yaitu (1) guru-guru secara lisan menyambut baik kegiatan pengabdian yang dilakukan, (2) orang tua atau wali murid sangat mendukung dan antusias dengan permainan-permainan yang dilakukan oleh anak-anak mereka selama dua hari, (3) guru termotivasi untuk dapat menguasai berbagai macam permainan dan ice-breaking untuk meningkatkan kualitas pembelajaran, dan (4) harapan adanya kelanjutan kegiatan pengabdian dan perluasan kegiatan pengabdian ini khusus untuk guruguru PAUD dalam satu kelurahan Pekayon khususnya kegiatan ice-breaking, permainanpermainan edukatif dan media pembelajaran bagi anak usia dini.

\section{KESIMPULAN \& SARAN}

Kegiatan pengabdian yang telah dilaksanakan menghasilkan beberapa simpulan yaitu:
1) Kegiatan "PKM Penanaman Nilai Karakter Melalui Permainan Outdoor Bagi Anakanak Usia Dini di Wilayah RW 01 Kel. Pekayon Kec. Pasar Rebo Jakarta Timur" memberi gambaran dan arahan kepada guru bahwa melakukan penanaman karakter siswa dapat melalui permainan-permainan outdoor sederhana yang bersifat edukatif.

2) Permainan-permainan outdoor yang bersifat edukatif memberi kesempatan kepada siswa belajar bekerjasama, kekompakan, toleransi, kejujuran, kedisiplinan, kerja keras, meningkatkan kreativitas, mandiri, demokratis, rasa ingin tahu, semangat kebangsaan, menghargai, kepemimpinan, kerjasama, peduli lingkungan, peduli sosial, tanggung jawab, religius, dan gemar membaca.

Adapun saran untuk kegiatan pengabdian selanjutnya yaitu perlunya pelatihan dalam skala lebih besar kepada guru-guru PAUD di wilayah kelurahan Pekayon sehingga pengetahuan guru terkait permainan edukatif lebih meningkat.

\section{DAFTAR PUSTAKA}

Abdullah, M. Y., Hastuti, W., \& Karmila, A. 2015. Lego (Puzzle Binggo) Games: Media Edukatif Berbasis Pendidikan Karakter Pada Anak Usia Sekolah Dasar dalam Mewujudkan Generasi Indonesia Emas. Jurnal PENA, 2 (1), 296-307.

Amylia, Linda R. dan Sri Setyowati. 2014. Pengaruh Outdoor Learning Terhadap Kemampuan Mengenal Konsep Bilangan Anak Kelompok A di TK Tunas Harapan Menongo Sukodadi. Jurnal PAUD Teratai Vol 3, No. 3 Tahun 2014

Fadlillah, M. 2016. Penanaman Nilai-Nilai Karakter Pada Anak Usia Dini Melalui Permainan-Permainan Edukatif. Dalam Prosiding Seminar Nasional "Pengintegrasian Nilai Karakter dalam Pembelajaran Kreatif di Era Ekonomi ASEAN".

Innayah. 2012. Media Audio Pembelajaran Untuk Pendidikan Dini dengan Model Permainan. Jurnal Majalah Ilmiah Pembelajaran No. 1 (2012)

Khoiri, Qolbi. 2018. Dimensions Of Islamic Education In The Prevention Bullying; Assesing In An Effort Of Charater Building For Children In School. Jurnal Publikasi Pendidikan, Tahun 2018, Vol. 8 , No. 2, Juni 2018 
Marzuki dan Lysa Hapsari. 2015.

Pembentukan Karakter Siswa Melalui Kegiatan Kepramukaan di MAN 1 Yogyakarta. Jurnal Pendidikan Karakter, Tahun V, No. 2 Oktober 2015

Susilowati, R. 2014. Strategi Belajar Outdoor Bagi Anak PAUD. Thufula, 2 (1), 65-82. 